\title{
The soil inorganic phosphorus distribution of vegetation-growing concrete substrate in the disturbed engineering area
}

\author{
Xin $\mathrm{Ma}^{1, \mathrm{a}}$,Wennian $\mathrm{X} \mathrm{u}^{1, \mathrm{~b}}$, Zhenyao Xia ${ }^{2, \mathrm{c}}$, Yajing Wang ${ }^{1, \mathrm{~d}}$, Shifeng Guan ${ }^{3, \mathrm{e}}$, \\ Linlin Zhang ${ }^{4, f}$
}

\author{
${ }^{1}$ College of biological \& pharmacy,China Three Gorges University, Yichang 443002,China \\ ${ }^{2}$ Collaborative Innovation Center for Geo-Hazards and Eco-Environment in Three Gorges Area, \\ Yichang443002, China \\ ${ }^{3}$ College of Hydraulic \& Environmental Engineering,China Three Gorges University, Yichang \\ 443002, China \\ ${ }^{4}$ College of Civil Engineering \& Architecture,China Three Gorges University, Yichang 443002, China

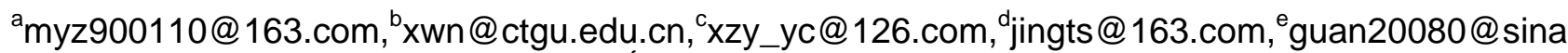 \\ .com, 'quingtianzhangll@163.com
}

Keywords: vegetation concrete, phosphorus, form, root system.

\begin{abstract}
This work presents the field and experimental studies conducted in China Three Gorges University, Yichang City, Hubei Province that reveal the distribution of inorganic phosphorus in four vegetation concrete samples and one natural forest sample. Several results of these studies have general application and include the following: (1) The total content of phosphorus in the five sample soil is $880 \sim 4,870 \mathrm{mg} / \mathrm{kg}$. (2) The phosphorus content of seat earth from all samples is all greater than that of topsoil and the content of total inorganic phosphorus is $258.194 \sim 1,591.084 \mathrm{mg} / \mathrm{kg}$, which accounts for $18.809 \%$ 38.364\% of total phosphorus. (3) The contents of inorganic phosphorus in four forms are orderly: $\mathrm{Ca}-\mathrm{P}>\mathrm{O}-\mathrm{P}>\mathrm{Al}-\mathrm{P}>$ water-soluble $\mathrm{P}$, and the content of $\mathrm{Ca}-\mathrm{P}$ reaches $230.76 \sim 579.85 \mathrm{mg} / \mathrm{kg}$. For the fact that the five slopes restored in the disturbed area of China Three Gorges University, the contents of water-soluble P, Al-P, O-P, Ca-P in the vegetation concrete soil are greater than that in the natural forest. This means that the content of $\mathrm{P}$ in the soil restored by manpower is higher than that in the natural forest, but the P contents in topsoil is lower than that in the seat earth at the same site caused by natural weathering, vegetation destruction and other problems.
\end{abstract}

\section{Introduction}

Phosphorus is one of the major and indispensable nutrition elements for plants growth and development. Its abundance ranks 11th in the earth's crust and its content of 1,180mg/kg-1 follows behind aluminum ${ }^{[1]}$. According to a report, the low- phosphorus cultivated land accounts for about $43 \%$ of 1.319 billion cultivated land in the world; $74 \%$ of 0.107 billion hm2 cultivated land in China lacks phosphorus ${ }^{[2,3]}$. As a result, phosphorus content is one of direct factors to influence plants growth and soil fertility. Phosphorus exits in soil in many different forms which mainly include water-soluble P, Al-P, O-P, Ca-P and Fe-P. For phosphorus in soil, different forms have different chemical properties and functions. Scholars at home and abroad had made a lot of researches and explorations on the form of phosphorus and mainly focused on the exploration and improvement in grading methods of phosphorus in soil ${ }^{[4,5,6,7]}$. The purpose of grading phosphorus in soil is to evaluate its scale of effective phosphorus and supply situation ${ }^{[8,9,10]}$.

\section{Material and method}

Sample collection and collection method.All soil samples were collected respectively in reception center, administrative building, computer building, library and Cuiping hill in China Three Gorges University. The five sites were respectively marked by A, B, C, D and E, which are all vegetation concrete slopes. Every sample soil were collected in surface layer and root in $S$ shape and 
collected in five points in every sample site. The samples were dried in the shade and the root system in them were removed. Then they were grinded and screened by $2 \mathrm{~mm}$ mesh screen. Finally, we collected $2 \mathrm{~kg}$ soil sample in every site using the point-quarter method. All samples were sacked for reserve.

Total P content of the soil was determined by digesting samples with concentrated H2SO4 and HClO4 and measuring it by colorimetric method, grouped soil inorganic phosphorus was measured by the method proposed by Zhang Shoujing and Jackson (year 1957), and rapidly available phosphorus was determined by using $0.5 \mathrm{~mol} \cdot \mathrm{L}-1 \mathrm{NaCO}$ to extract the phosphorus in the soil and showed color of the phosphorus in the sample under test by using molybdenum antimony anti reagent, and then measured the content of phosphorus as per spectrophotometry.

\section{Results and analysis}

The content distribution of total phosphorus and inorganic phosphorus in all sorts of forms in two kinds of restored slopes in the disturbed area of China Three Gorges University

The research was made on the distribution features of inorganic phosphorus on four vegetation concrete slopes and one natural forest site of China Three Gorges University by adopting the inorganic phosphorus distribution system proposed by Zhang Shoujing and Jackson. Table 1 and Table 3 show that the content of total inorganic phosphorus in the five sample sites is between 258.19 and $1,591.08 \mathrm{mg} / \mathrm{kg}$, which accounts for $18.81 \%-38.36 \%$ of total phosphorus. According to some scholars' researches, the inorganic phosphorus in soil is the main source of nutrition needed by plants and that accounts for $60 \%-80 \%$ of the total phosphorus ${ }^{[11]}$. In the five slopes in two restored modes of China Three Gorges University, the inorganic phosphorus only accounts for a little of the total phosphorus, which obviously lower than normal level. In table 1 , the content of total inorganic phosphorus in vegetation concrete soil is between $263.335 \mathrm{mg} / \mathrm{kg}$ and $1591.08 \mathrm{mg} / \mathrm{kg}$ and its average content is $1,123.81 \mathrm{mg} / \mathrm{kg}$. The content of total inorganic phosphorus in natural forest soil is between $258.194 \mathrm{mg} / \mathrm{kg}$ and $317.076 \mathrm{mg} / \mathrm{kg}$ and its average content is $287.64 \mathrm{mg} / \mathrm{kg}$. Among the samples, the content of inorganic phosphorus in root soil in four vegetation concrete sample sites is $322.82-1591.08 \mathrm{mg} / \mathrm{kg}$ and its average content is $1,183.15 \mathrm{mg} / \mathrm{kg}$; the content of inorganic phosphorus in non-root soil in four vegetation concrete sample sites is $253.33-1426.51 \mathrm{mg} / \mathrm{kg}$ and its average content is $1,064.47 \mathrm{mg} / \mathrm{kg}$. Although the content of inorganic phosphorus in root soil is greater than that in the non-root soil, the difference is not obvious. Table 2 shows the content distribution of inorganic phosphorus in all sorts of forms of five sample sites under test. The distributions are as follows: water-soluble P: slope of administrative building $>$ slope of library $>$ slope of computer building > slope of reception center $>$ Cuiping mountain; Al-P: slope of computer building > slope of library $>$ slope of administrative building $>$ slope of reception center $>$ Cuiping mountain;O-P: slope of computer building $>$ slope of administrative building $>$ slope of library $>$ slope of reception center $>$ Cuiping mountain; Ca-P: slope of library $>$ slope of administrative building $>$ slope of computer building $>$ slope of reception center $>$ Cuiping mountain. The content order of phosphorus in four forms in the five sample sites under test is $\mathrm{Ca}-\mathrm{p}>\mathrm{O}-\mathrm{P}>\mathrm{Al}-\mathrm{P}>$ water-soluble $\mathrm{P}$. The content of Ca-P is up to $230.76-579.85 \mathrm{mg} / \mathrm{kg}$, which accounts for the highest percentage among the four forms; the content of water-soluble P is $4.18-77.95 \mathrm{mg} / \mathrm{kg}$, which accounts for the lowest percentage among the four forms. This shows that Ca-P is the most effective among the four forms and the soil-fixing strength of slope is very strong due to the lowest content of water-soluble $\mathrm{P}^{[12]}$. 
Table 1 The contents of total phosphorus, total inorganic phosphorus and rapidly available phosphorus in two kinds of slopes in the disturbed area of China Three Gorges University

\begin{tabular}{|l|l|l|l|l|l|}
\hline No. & $\begin{array}{l}\text { Sample site } \\
\text { name }\end{array}$ & Soil type & $\begin{array}{l}\text { Total } \\
\text { phosphorus[mg/kg } \\
{[}\end{array}$ & $\begin{array}{l}\text { Total inorganic } \\
\text { phosphorus[mg/kg] }\end{array}$ & $\begin{array}{l}\text { Rapidly available phosphorus } \\
{[\mathrm{mg} / \mathrm{kg}]}\end{array}$ \\
\hline A-1 & $\begin{array}{l}\text { Cuiping } \\
\text { mountain }\end{array}$ & Natural forests & 1.058 & 317.0763 & 54.474 \\
\hline A-2 & $\begin{array}{l}\text { Cuiping } \\
\text { mountain }\end{array}$ & Natural forests & 0.672 & 258.194 & 65.368 \\
\hline B-1 & $\begin{array}{l}\text { Administrati } \\
\text { ve building }\end{array}$ & Vegetation concrete & 4.475 & 1365.972 & 350.450 \\
\hline B-2 & $\begin{array}{l}\text { Administrati } \\
\text { ve building }\end{array}$ & Vegetation concrete & 4.871 & 1591.084 & 325.029 \\
\hline C-1 & $\begin{array}{l}\text { Computer } \\
\text { building }\end{array}$ & Vegetation concrete & 4.427 & 1426.505 & 499.346 \\
\hline C-2 & $\begin{array}{l}\text { Computer } \\
\text { building }\end{array}$ & Vegetation concrete & 4.539 & 1588.764 & 513.872 \\
\hline D-1 & $\begin{array}{l}\text { Library } \\
\text { D-2 }\end{array}$ & Vegetation concrete & 3.761 & 1202.077 & 470.293 \\
\hline E-1 & $\begin{array}{l}\text { Reception } \\
\text { center }\end{array}$ & Vegetation concrete \\
center & 0.880 & 1229.947 & 453.951 \\
\hline E-2 & Veception & Vegetation concrete & 1.399 & 322.8203 & 130.737 \\
\hline
\end{tabular}

Note: -1 stands for non-root soil, -2 stands for root soil

Table 2 The contents of inorganic phosphorus in all sorts of forms in soil

\begin{tabular}{|c|c|c|c|c|c|}
\hline No. & $\begin{array}{l}\text { Sample site } \\
\text { name }\end{array}$ & $\begin{array}{l}\text { Water-soluble P } \\
{[\mathrm{mg} / \mathrm{kg}]}\end{array}$ & $\begin{array}{l}\text { Al-P } \\
{[\mathrm{mg} / \mathrm{kg}]}\end{array}$ & $\begin{array}{l}\mathrm{O}-\mathrm{P} \\
{[\mathrm{mg} / \mathrm{kg}]}\end{array}$ & $\begin{array}{l}\text { Ca-P } \\
{[\mathrm{mg} / \mathrm{kg}]}\end{array}$ \\
\hline$\overline{A-1}$ & $\begin{array}{l}\text { Cuiping } \\
\text { mountain }\end{array}$ & 5.871 & 1.806701 & 72.26811 & 237.1297 \\
\hline A-2 & $\begin{array}{l}\text { Cuiping } \\
\text { mountain }\end{array}$ & 4.177 & 0.677378 & 22.57928 & 230.7602 \\
\hline B-1 & $\begin{array}{l}\text { Administrativ } \\
\text { e building }\end{array}$ & 74.193 & 364.4068 & 646.9294 & 505.555 \\
\hline B-2 & $\begin{array}{l}\text { Cuiping } \\
\text { mountain }\end{array}$ & 77.949 & 343.608 & 383.5415 & 560.873 \\
\hline$\overline{C-1}$ & $\begin{array}{l}\text { Computer } \\
\text { building }\end{array}$ & 50.813 & 379.9722 & 537.494 & 458.225 \\
\hline $\mathrm{C}-2$ & $\begin{array}{l}\text { Computer } \\
\text { building }\end{array}$ & 58.884 & 379.7061 & 573.0561 & 577.1171 \\
\hline D-1 & Library & 59.868 & 374.0095 & 188.3501 & 579.8492 \\
\hline$\overline{\mathrm{D}-2}$ & Library & 61.604 & 372.6736 & 221.1445 & 574.5243 \\
\hline E-1 & $\begin{array}{l}\text { Reception } \\
\text { center }\end{array}$ & 12.381 & 10.8057 & 50.52138 & 259.1117 \\
\hline E-2 & $\begin{array}{l}\text { Reception } \\
\text { center }\end{array}$ & 6.772 & 10.49727 & 62.029908 & 237.0351 \\
\hline
\end{tabular}

Note: -1 stands for non-root soil, -2 stands for root soil 
Table 3 The ratio of total inorganic phosphorus and inorganic phosphorus in all sorts of forms in soil

\begin{tabular}{|l|l|l|l|l|l|l|}
\hline No. & Sample site name & $\begin{array}{l}\text { Total inorganic } \\
\text { phosphorus } \\
{[\%]}\end{array}$ & $\begin{array}{l}\text { Water-soluble } \\
\text { P } \\
{[\%]}\end{array}$ & $\begin{array}{l}\text { Al-P } \\
{[\%]}\end{array}$ \\
\hline A-1 & Cuiping mountain & 29.969 & $\begin{array}{l}\text { O-P } \\
{[\%]}\end{array}$ & \\
\hline A-2 & Cuiping mountain & 38.364 & 0.554 & 0.170 & 6.830 \\
\hline B-1 & Administrative building & 35.547 & 0.620 & 0.100 & 3.355 \\
\hline B-2 & Administrative building & 28.037 & 1.657 & 8.141 & 14.453 & 11.294 \\
\hline C-1 & Computer building & 31.427 & 1.599 & 7.052 & 7.872 \\
\hline C-2 & Computer building & 35.888 & 1.119 & 8.371 & 11.841 & 10.095 \\
\hline D-1 & Library & 31.961 & 1.330 & 8.577 & 12.944 & 13.036 \\
\hline D-2 & Library & 28.643 & 1.591 & 9.944 & 5.007 \\
\hline E-1 & Reception center & 36.684 & 1.434 & 8.678 & 5.150 \\
\hline E-2 & Reception center & 18.809 & 1.406 & 1.227 & 5.604 \\
\hline
\end{tabular}

Note: -1 stands for non-root soil, -2 stands for root soil

\section{Conclusions}

The content of total inorganic phosphorus in the five sample sites of China Three Gorges University is between 258.19 and $1,591.08 \mathrm{mg} / \mathrm{kg}$ and the content of total phosphorus is $0.672-4.871 \mathrm{~g} / \mathrm{kg}$, among which inorganic phosphorus accounts for $18.81 \%-38.36 \%$ of total phosphorus. The content of inorganic phosphorus is lower than normal level. Although the content of inorganic phosphorus in root soil is greater than that in the non-root soil, which may be caused by the negative physiological activity of plants' roots due to the decrease in phosphorus in the vegetation concrete with rainfall, weathering and other natural factors, the difference is not obvious. The content of total inorganic phosphorus in four vegetation concrete slopes is between $263.335 \mathrm{mg} / \mathrm{kg}$ and $1591.08 \mathrm{mg} / \mathrm{kg}$ and the content of total inorganic phosphorus in one natural forest slope is between $258.194 \mathrm{mg} / \mathrm{kg}$ and $317.076 \mathrm{mg} / \mathrm{kg}$. Their average contents in these two kinds of slopes respectively are $1,123.81 \mathrm{mg} / \mathrm{kg}$ and $287.64 \mathrm{mg} / \mathrm{kg}$. Through comparison, the content of inorganic phosphorus in restored vegetation concrete slope is greater than that in natural forest soil.

The content order of phosphorus in four forms in the five sample sites under test is Ca-p $>\mathrm{O}-\mathrm{P}>\mathrm{Al}-\mathrm{P}>$ water-soluble $\mathrm{P}$. Ca-P is the most effective phosphorus source in restored vegetation concrete slope among the four forms, and the soil-fixing strength of slope is very strong due to the low content of water-soluble P.

\section{Acknowledgements}

This work was supported by the Open Fund (No. KF2013-10) and the Natural Science Foundation of China (No. 51278281).

\section{References}

[1] GRUNWALD S, CORSTANJE R, WEINRICH B E, et al. Spatial patterns of labile forms of phosphorus in a subtropical wetland [J]. Journal of Environmental Quality, 2006, 35(1): 378- 389.

[2] Wang Yilun, Zhang Xu, Tan Jinfang, Han Yanlai. Problem and Solutions of Soil and Fertilizers in Agricultural Sustainable Development[J]. Chinese Agricultural Science Bulletin, 2008,24(11):278-281.

[3] Sheng Xuebin, Sun Jianzhong. Status and trends on soil phosphorus[J]. Advances in Environmental Science, 1995,3(2):11-21. 
[4]Y. Geng, J. Chen, K. Pahlavan, Motion detection using RF signals for the first responder in emergency operations: A PHASER project, 2013 IEEE 24nd International Symposium on Personal Indoor and Mobile Radio Communications (PIMRC), London,Britain Sep. 2013

[5]Y. Geng, J. He, K. Pahlavan, Modeling the Effect of Human Body on TOA Based Indoor Human Tracking[J], International Journal of Wireless Information Networks 20(4), 306-317 [5] Yang Liling, Yang Xueyun. Research Advance in the Assess men t of Phosphor us For min Soil[J]. Journal of Anhui Agri.Sci, 2006,34(19):4996-4997. 